\title{
A JÁTÉK JELENTŐSÉGE - A TANULÁSBAN AKADÁLYOZOTTAKKAL FOGLALKOZÓ GYÓGYPEDAGÓGUSOK ÉS TÖBBSÉGI PEDAGÓGUSOK JÁTÉKHASZNÁLATA A TANÍTÁSI ÓRÁKON
}

\author{
Szerzők: \\ Bánki Beáta \\ Szabolcs-Szatmár-Bereg Megyei Pedagógiai \\ Szakszolgálat Nyírbátori Tagintézménye \\ (Magyarország) \\ Hegedűs Roland (PhD.) \\ Debreceni Egyetem (Hungary) \\ Levelező szerző e-mail címe: \\ hegedusroland1989@gmail.com
}

\section{Lektorok:}

\author{
Kerülő Judit (PhD.) \\ Nyíregyházi Egyetem (Magyarország)
}

Mező Katalin (PhD.)

Debreceni Egyetem (Magyarország)

...és további két anonim lektor

Bánki Beáta, Hegedûs Roland (2021). A játék jelentősége - a tanulásban akadályozottakkal foglalkozó gyógypedagógusok és többségi pedagógusok játékhasználata a tanítási órákon. Különleges Bánásmód, 7. (3). 726. DOI 10.18458/KB.2021.3.7

\begin{abstract}
Absztrakt
Napjainkban a pedagógia kiemelt feladata a képességek fejleszté se és az alapvető kompetenciák kialakítása, mert ezek szükségesek a sikeres tanítási-tanulási folyamathoz. Az eddigi hagyományos, a tanulót passzív befogadóként kezelő frontális oktatással szemben, a jelenlegi oktatás egyre nagyobb hangsúlyt fektet a felfedező, saját tapasztalaton, élményen alapuló, cselekvéses tanulásra, ismeretszerzésre, melynek alapja lehet a játék, a játékos tevékenység. A játéknak kiemelt szerepe van a képességek és a személyiség fejlesztésében, ezért kutatásunkban a játék szerepét vizsgáljuk a tipikus és a tanulásban akadályozott gyermekek tanítása folyamán. A vizsgálat során online kérdőívet használtunk, amit HajdúBihar és Szabolcs-Szatmár-Bereg megyében, iskolában dolgozó gyógypedagógusokhoz és többségi pedagógusokhoz juttatunk el célirányos megkereséssel ( $\mathrm{N}=102$ fö). A válaszok eloszlása egyenletes tagozatra és iskolatípusra vonatkozóan, így 25 és 26 fős csoportokat tudtunk kialakítani. Eredményeinkben visszatükröződik a pedagógusok által használt eltérő oktatási módszer, ugyanis a gyógypedagógusok sokkal gyakrabban alkalmaznak játékokat munkájuk során és sokkal több időt is szánnak rá, mint a többségi pedagógusok. A gyógypedagógusok sokkal több fejlesztő hatást tulajdonítanak a játéknak, ezért felső tagozatos gyerekek körében is gyakrabban használják. A többségi pedagógusoknál inkább dominálnak az infokommunikációs eszközök, míg a gyógypedagógusok több saját készítésú eszközt használnak. A módszerek tekintetében a pedagógusok a differenciálást tartják a legfontosabbnak, amit a szemléltetés és kooperatív tanulás követ, míg a játék a negyedik helyre került.
\end{abstract}


Kulcsszavak: játék; motiváció; tanulási képesség; tanulásban akadályozottság; gyógypedagógus, többségi pedagógus

Diszciplína: pedagógia

\begin{abstract}
THE IMPORTANCE OF PLAY - THE USE OF GAMES BY SPECIAL EDUCATIONAL NEEDS TEACHER AND MAJORITY TEACHERS IN LESSONS

Nowadays, the priority task of pedagogy is to develop skills and basic competencies, because these are necessary for a successful teaching-learning process. In contrast to the traditional frontal education, which the learners treat as a passive recipient. The current education places more and more emphasis on exploration, action-based learning and knowledge acquisition based on one's own experiences, which can be based on play and playful activity. Game plays a key role in the development of skills and personality, so in this research, we examine the role of game in the teaching of typical and learning disabilities children. During the study, we used an online questionnaire, which was sent to special educational needs teachers and majority teachers working in schools in Hajdú-Bihar and Szabolcs-Szatmár-Bereg counties $(\mathbb{N}=102$ people). The distribution of the answers was even for each grade and school type, so we were able to form groups of 25 and 26 people. Our results reflect a different teaching method because special educational need teacherss use games much more often in their work and spend much more time on it compared to majority teacheris. Special educational needs teachers attribute much more developmental effects to the game, so they use it more often in upper grades as well. The majority teaxhers are dominated by infocommunication tools, while special educational need teachers use several self-made tools. In terms of methods, teachers consider differentiation to be paramount, followed by illustration and cooperative learning, while playing came in fourth place.
\end{abstract}

Keywords: game; motivation; learning skill; learning disabilities; special educational needs teacher, majority teacher

\title{
Discipline: pedagogy
}

\section{Bevezetés}

A tanulás komoly erőfeszítést igénylő, igen megterhelő folyamat, amin sokat könnyíthet a pedagógus megfelelő szervezéssel, optimális módszerek kiválasztásával, alkalmazásával. A pedagógia fejlődésének köszönhetően számos módszer közül választhat a pedagógus, attól függően, hogy milyen célt kíván elérni. Vizsgálatunkban ezek közül a játék módszerét kívánjuk részletesebben bemutatni, mert ez rendkívül sokszínú, sokoldalú, így bármelyik korosztályban és tantárgy keretében, bármely cél elérése érdekében alkalmazható. Több év- százados tapasztalatok bizonyítják a játék helyét az oktatási-nevelési módszerek között, melynek segítségével a pedagógusok sokoldalúan fejleszthetik a tanulók kompetenciáit. A játék örömöt jelent a gyermek számára, ezért nevelési szempontból az érzelmekre gyakorolt hatása miatt is kiemelkedő jelentőséggel bír. Témaválasztásunkat indokolja az a tény is, hogy napjainkban a pedagógia kiemelt feladata a képességek és az alapvető kompetenciák kialakítása, fejlesztése, mert ezek nélkülözhetetlenek a sikeres tanítási-tanulási folyamathoz. A játéknak kiemelt szerepe van a személyiség fejlesz- 
tésében is, ezért vizsgáljuk szerepét a tipikus és a tanulásban akadályozott gyermekek tanítása folyamán. A téma aktualitását az is indokolja, hogy az eddigi hagyományos, a tanulót passzív befogadóként kezelő frontális oktatással szemben a jelenlegi oktatás egyre inkább hangsúlyt fektet a felfedező, saját tapasztalaton, élményen alapuló, cselekvéses tanulásra, melynek alapja lehet a játék, a játékos tevékenység.

A pedagógusoknak igen nagy kihívást jelent elérni azt az állapotot, hogy a tanulók aktívan részt vegyenek a tanítás-tanulási folyamatában, és mindezt úgy kell megtenniük, hogy a gyermek számára az ne legyen riasztó, illetve ne túnjön mereven oktatásközpontúnak. További nehézséget jelenthet a súlyos tanulási nehézséggel küzdő, tanulásban akadályozott gyermekek megfelelő motiválása, akiknél a negatív szociális környezeti hatások és a tanulásban fennálló sikertelenségek hatására a tanulási motiváció jelentősen csökkenhet. Az aktivitást, illetve motivációt vesztett tanulók helyzetében az egyedüli és igazán eredményes motivációs alapot a pedagógus személyisége és a játék jelentheti. A tanulásban akadályozott gyermekekre jellemző, hogy különböző képességeik (kognitív képességek, motoros és orientációs képességek, emocionális és szociális képességek, kommunikációs képességek) fejlődése lassabb ütemú a többségi társaikhoz képest, ezért ezeknek a képességeknek a fejlesztésében, illetve a tanulásban akadályozott gyermekek oktatásában-nevelésében, valamint megsegítésében rendkívül hatékony eszközként szolgál a játék, illetve a játékos tevékenység. Czibere és Kisvári (2006. 31.) a következőképpen foglalja össze a játék gyógypedagógiában betöltött szerepét: „A játékos gyakorlatok, játékok a feldolgozás alappillérei. Minden más módszer, eljárás, tevékenység a játékhoz kapcsolódjon. Ez a helyzet a felszabadult, a spontaneitást, az ötletközlési, önkifejezési, kapcsolatalakítási, helyzetmegoldási bátorságot és a lelkes részvételt támogatja. Oldott, elfogadott, megítélésmentes és minősítésmentes klímát teremt. A nyilt, őszinte, a visszautasítástól és a kudarctól megkímélő légkörben könnyebben kialakul a gyermeki aktivitás, a kölcsönös támogatás és támogatottság, valamint a csoportszabályok betartása és az elvárásoknak való megfelelés."

A játékos módszerekre jellemző, hogy mindig sokrétúek, komplexek, emellett a hagyományos frontális osztálymunka - melynek során a tanulók passzív befogadó szerepbe kerülnek - mérséklésére is alkalmat adnak, teret engedve a csoportos és differenciált egyéni munkaformáknak. A játékos tevékenység nyújtotta élménnyel olyan maradandó emléknyomok keletkezhetnek, amikhez már könnyebben kapcsolhatók az új ismeretek. A játék akkor éri el célját, ha megfelelő, tényszerű tudásra alapozzuk, tehát meg kell elóznie az ismeretszerzésnek, az összefoglalásnak, a rendszerezésnek, csak így válhat pedagógiai értelemben is hatekonnyá (Miltényi, 1992).

\section{A játék fogalmának meghatározása és alapvető jellemzői}

A játék ősidőktől fogva jelen van az emberiség történelmében, kortól és nemtől független tevékenységi forma. Olyan teret biztosít a résztvevők számára, ahol nincsenek különbségek, mindenki egyenlőnek számít. Spontán kialakuló, önfeledt cselekvés, ami folyamatosan, a gyerekkortól az idôskorig végig kíséri az ember életét. A játék és játékos tevékenység főképp a gyermekek életében tölt be meghatározó szerepet, mert számukra alapvető, mindennapi tevékenységként van jelen. A gyermekek fejlődése során a játéknak fontos funkciója van személyiségük alakulásában, ezért módszertani alkalmazása óriási lehetóséget nyújthat a pedagógusok számára (Kovács és Bakosi, 2005).

A játék szó az emberek többségéből pozitív, kellemes érzést vált ki, mert ugyan egyszerû szónak túnik, mégis sokféle tartalommal bír. Jelenthet cselekvést, tevékenységet, tárgyat, eljárást, de jelölhet számos megnyilvánulási formát, mozgást is, például 
színjáték, vígjáték vagy a fény és árnyék játéka, a képzelet játéka stb. (Detre és Szigeti, 1980).

A szakirodalom a játék fogalmát különbözô szemszögből vizsgálva többféleképpen fogalmazza meg. Lányiné szerint „A játék örömet, szórakozást jelent, a felnőtt számára üdülést, a gyermek számára ujjongó, szenvedélyes kutatást, valóság megismerést." (Lányiné, 1992. 67.). Az eltérő nézetek ellenére megfigyelhetô néhány közös jellemző, amiket jól összefoglal a következő játékfogalom: „A játék külső céltól függetlenül magáért a tevékenységért való, melyet örömérzés kísér. E meghatározáson belül helyezhetjük el a gyermek játékát, mely a gyermek olyan sajátos öntevékenysége, ami szabad akaratára épül, benne és általa érvényesül legtipikusabban és legsokoldalúbban önkifejezése, s ezáltal környezethez való viszonya." (Kovács és Bakosi, 2005. 13.).

A gyermek a játékos tevékenység közben létrejött önfeledt helyzetben mutatja meg legőszintébben, legnyíltabban önmagát, ezért a pedagógus számára ez az egyik legkedvezőbb alkalom, hogy átfogó képet kapjon az általa nevelt/tanított gyermekekről. A gyermek állapotának megismerése, felmérése céljából a játék lehet az egyik leghatékonyabb diagnosztikai célokra szolgáló vizsgálati eszköz (Mérei és V. Binét, 2006).

Ahogyan a gyermek fejlódik, úgy változik a játéktevékenysége is, ezért a játékot mindig a gyermek képességeihez, fejlettségi szintjéhez kell igazítani, hogy abban sikerélménye lehessen, de fontos megtartani az egyensúlyt a gyermeki önérvényesítés támogatásának mértéke és az alkalmazkodás mértéke között, ezáltal fejlődhet a játék. Eredményes játék leginkább biztonságos, nyugodt légkörben kialakult, közepesen erős izgalmi állapot mellett lehetséges, mert a túlzottan magas izgalmi állapot félelmet, szorongást, agressziót kelthet a gyermekben, ha pedig túl alacsony mindez, akkor nincs számára kihívás, unalmas, kedvetlen állapotot eredményez. Ideális körülmények között a játékra öröm, izgatottság, kellemes hangulat, felszaba- dultság, könnyedség, nevetés jellemző, amikor a résztvevők teljesen átengedik magukat a játék okozta élménynek, megfeledkeznek önmagukról, a félelmeiktől és a negatív külső hatásoktól (Stöckert, 1995). A játékban résztvevők sikerélményhez jutnak, így a játéktevékenység pótolhatja a valós életben el nem ért sikerélményt, ezzel is erősítve a játékosok önbizalmát, akik emiatt később ismételten át szeretnék élni a játék nyújtotta élményt. A játék során lehetőség nyílik a „,nehéz élmények” feldolgozására, a különféle érzelmeink kifejezésére, egyfajta öngyógyító szerepet biztosít, emellett kitartásra nevel, ugyanis, ha a gyermek érzi a pedagógus bizalmát, támogatását, akkor a nehézségek ellenére is kitart, próbálkozik újra és újra (Mérei és V. Binét, 2006).

A játék szabályokra épül, amiket a játékosok közösen hoznak, és a játékban résztvevőkre nézve kötelező érvényűek, ezért a játékot kettősség jellemzi. Egyrészt a játékos szabadnak érzi magát a játékban, ugyanakkor be is kell tartania a közösen hozott szabályokat. A játéktevékenység során kialakul a szabálytudat, az egymáshoz való alkalmazkodás, az együttmúködés, fejlődik a szociális kompetencia. A beszédnek is fontos szerepe van, mert ez biztosítja a játékszabályok megfogalmazását, illetve a játékban résztvevő személyek egymás közötti kommunikációját. A közös munka igényli a megszerzett tudás cselekvésbe ágyazott, rendszerezett újra alkalmazását (Stöckert, 1995). „A gyermeknek a játék a legfontosabb, a legalapvetôbb tevékenysége; a reális valóság megismerésének eszköze, melyben egész személyisége formálódik. A játékban rejlő pedagógiai lehetôségeket az iskolai nevelésben is fel lehet használni, mert a játék iránti érdeklődés, vonzalom az iskolás korú gyermekeknél is megmarad, és bár tevékenységük alapvető formája a tanulás, emellett a játék sokoldalú fejlesztő, nevelő hatásait is érvényesíteni lehet." (Detre és Szigeti, 1980. 25.).

A játék és a tanulás viszonya egymással nem ellentétes, hanem szorosan összekapcsolódó, 
kölcsönhatásként értelmezhetô, ami a gyermek érésével együtt fejlődik. A játékon belüli tanulás azért lehet hatásosabb minden más tanulási formával szemben, mert a gyermek szükségleteire támaszkodik, igényeihez, vágyaihoz igazodik (Kovács és Bakosi, 2005). A tanítás során használt, jól megválasztott játékok számos készséget és képességet fejlesztenek, emellett a játék élményszerűséget, tevékenykedtetést, valamint tapasztalaton alapuló ismeretszerzést biztosít a tanulásban. Az egyhangú tanórai munkát felpezsdíthetjük egy remek játékkal, és a rendszeresen alkalmazott, megfelelően kiválasztott játékok izgalmasabbá, érdekesebbé tehetik az órai munkát. A játék a tanulót önálló, rendszerező gondolkodásra neveli, ezáltal új és váratlan helyzetekben a megszerzett ismeretek felidézése, alkalmazása nem jelent számára gondot. A játékos tevékenység megtöri az egyhangúvá vált, monoton munkát, és segíti a gyermek aktív jelenlétét az iskolai tevékenységekben, valamint a tanulásban. A játék által közvetlen kapcsolat alakul ki a pedagógus és a tanítványai, illetve a gyermekek tekintetében egymás között is. A játékban résztvevő gyermekek miközben játszanak, észrevétlenül fejlődnek társas alkalmazkodásukhoz nélkülözhetetlen képességeik és a tárgyhasználattal kapcsolatos módszertani kultúrájuk, emellett a játék az ismeretszerzés fontos eszköze, ahol cselekvés közben gyakorolják érzékszerveik használatát. Valamennyi játék során szükség van a figyelemre, az emlékezetre, a képzeletre és a gondolkodásra. Minél több érzékszerv kerül bevonásra, annál hatékonyabb az elsajátítás. $\mathrm{Az}$ iskolai években már inkább a játékosság, mint fogalom kíséri a megismeró vagy alkalmazó gyakorlást segítő tevékenységeket (Maár, 2009). „A játékok elősegítik a gyermekek spontán tevékenységét, fejlesztik kreativitásukat, a kommunikációt, az önkifejezést, a döntési kompetencia és a tanulási folyamat önkontrolljának kifejlődését, felkínálják a kognitív, szociális és motoros tanulás összes élményösszefüggését. Alkalmazhatók diagnosztizáláshoz (gyermekek megfigyeléséhez, megismeréséhez), terápiás eszközként (segítve a hátrányokat mutatók felzárkóztatását), akárcsak önálló tapasztalatszerzéshez, differenciáláshoz." (Réthy, 1985. 26.).

A játéknak alapvetően négy nagy típusát különböztethetjük meg. Születés után megjelenik a gyakorló vagy funkcionális játék, ami a 0-2 éves kor közötti időszakban a kisgyermek legjellemzőbb tevékenységi formája. A játékfajták ezen típusa a gyermek első játéka, melynek során a saját testével és a hangokkal, majd a környezete tárgyaival játszik, s ez megalapozza a későbbi időszak összetettebb játéktevékenységeit, a fogalmi rendszerek kialakulását és a kreatív gondolkodást (Balogh, 2008; Tunyogi, 2019).

A begyakorolt funkciójátékokra épülnek a később kialakuló konstruáló játékok, amik segítségével a gyermekek megtanulnak különbséget tenni dolgok között, térben és síkban tájékozódni, tárgyakkal mûveleteket végezni. A funkciójáték során erősödik a manipulációs készség, fejlődik a megfigyelés, az emlékezet, a képzelet és a problémamegoldás. A konstruktív játék állandóan formálódik, különböző formában - az adott életkorhoz illő változatban az emberek többségének életében folyamatosan jelen van (Tunyogi, 2019).

A gyakorló játékból formálódnak a szimbolikus játékok is, amikben a gyermek a kitalált vagy valós élményeit „mintha” helyzetben kelti életre. A szimbolikus játéktípusnak nélkülözhetetlen alkotó eleme a gyermek képzelő ereje, fantáziája, melyek segítségével teljesen beleéli magát az adott játékhelyzetbe. A játékot kettős tudat kíséri, ugyanis a gyermek az elképzelt játékvilág mellett pontosan tisztában van a reális, valóságbeli állapotával is (Kovács és Bakosi, 2005; Mérei és V. Binét, 2006).

A differenciáltabb szerepjátékokban megjelennek a szabályok, majd ebból az összetett formából fejlődnek ki a szabályjátékok, így a szerepek, mûveletek, eszközök lépcsőzetesen kerülnek a szabályok alárendelésébe. A szabályjátékok óvodáskor 
végén, hatéves korban már megjelennek a tipikusan fejlődő gyermekeknél, de legfőképp iskoláskorban jellemzőek, és az iskolások körében az egyik legkedveltebb játékfajtát jelentik (Detre és Szigeti, 1980). A szabályok nélkülözhetetlen részei a mindennapi életünknek, melyek mellőzése rendezetlen, zűrzavaros állapotok kialakulásához vezetne. A gyermek még nem eléggé fejlett ahhoz, hogy ezt felismerje, ezért a szabályjátékok segítenek neki abban, hogy feldolgozhassa környezetéhez való viszonyát, valamint az abban elfoglalt helyéhez kapcsolódó alá-, fölé- és mellérendeltségi viszonyokat (Tunyogi, 2019).

A szabályjáték közben a szabály dominál, hangsúlyossá téve azt, ugyanakkor betartása adja az öröm forrását is. Megjelenési formáját tekintve igen sokféle lehet, többnyire csoportos tevékenység. A szabálytudat kezdetben labilis, a játékban résztvevő gyermekek az általános szabályokat még eltérésekkel értelmezhetik, ezért célszerú ebben az időszakban minél egyszerúbb szabályokat alkalmazni. Hét-nyolc éves korban a gondolkodásban változás következik be, mert megjelennek a konkrét múveletek, melyek segítségével fejlődik a szabálytudat is, emellett a játékban kialakul az együttműködés és a szabályok betartásának ellenőrzése egymás között (Mérei és V. Binét, 2006).

\section{Motiváció és játék a tanulás folyamatában}

A tanulás olyan tevékenység, ami igyekezetet, fáradozást kíván meg a tanulótól, éppen ezért fontos tudni azt, hogy mi motiválja az egyént a tanulásra. A tanulási motivációt a nemzetközi szakirodalom általános meghatározása alapján Fejes (2015. 19.) a következőképpen adaptálta: „,a tanulási motiváció a tanulással összefüggő viselkedést elindító, fenntartó és irányító folyamat.” Egy olyan összetett jelenségről van szó, ami számos tényező együttes hatásaként jön létre, és amiben szerepet játszanak mind a tanulót érô külső hatások, mind pedig a belső pszichikus tényezők. A motiváció a tanítási munkán belül egyrészt megjelenik a pedagógus tevékenységében, amikor a diákok érdeklődését kívánja felkelteni, másrészt a tanulók pszichikus elemeinek fejlettségében, amik a tanulás belső feltételei is egyben (Józsa, 2007). „A tanulás folyamata nemcsak intellektuális teljesítmény, hanem egyidejűleg motivációs és emocionális megküzdési helyzet is." (Réthy, 2003. 44.).

A tanulás feltétele a motiváció, mert annak a személynek, aki ismeretet akar elsajátítani, kedvezően motiváltnak kell lennie a tanulás folyamán, melynek során a tanulási motiváció is formálódik, fejlődik. A motiváció egy belső erő, ami az egyént arra buzdítja, hogy megtalálja a tanulás örömét akkor is, ha esetleg korábban nem voltak sikerei. A nevelői-oktatói munka célja elérni azt az állapotot, hogy a gyermek megszeresse a tanulást, saját indíttatásból tanuljon, ami nagyon lényeges az én fejlődése aspektusából (Réthy, 2003). Ezt a következőképpen lehet megvalósítani: „ügyesen elvezetni a tanulót a valaki kedvéért való tanulástól odáig, hogy ő maga kedvét lelje a tanulásban" (Réthy, 2003. 81.).

A motiválás célja egy tanítási órán belül az, hogy kedvet ébresszünk a tanulókban, figyelmüket a tananyagra és annak megtanulására irányítsuk, illetve biztosítsuk az eredményes tanuláshoz szükséges feltételeket. Különféle tanulást motiváló tényezők léteznek, melyek a következők: a belülről hatást kifejtők, a kívülrôl szabályozók, direkt, indirekt, primer, szekunder, általános, speciális, beépült (internalizált), illetve a presztízsmotívumok. A cselekvések hátterét vizsgálva a motiváltság két típusa különböztethetô meg: az extrinzik és az intrinzik motiváció. Először a külső környezetből érkező vagy extrinzik motiváció jelenik meg, ami valamilyen külső cél eléréséért történik. Ekkor az egyén a környezete ösztönző hatására végez el egyegy feladatot, s ennek nincs köze a tanulás lényegéhez, attól független. Ezzel ellentétben a belső, önjutalmazó vagy intrinzik motivációról akkor beszélünk „ha a motivált állapot a tanulók 
meghatározott személyiségjegyei vagy a tanulási helyzet sajátosságai révén jön létre" (Réthy, 2003. 117.).

Amikor a tanulási motiváció fejlődik, a külső ösztönzốk belsôvé válnak, a tanulók már belső késztetést éreznek az eredményes tanulás iránt, saját maguk örömére érdeklődnek a tananyagról, és törekszenek annak elsajátítására. A tanulásban akadályozott tanulók tekintetében nagyrészt az extrinzik motiváció tölt be meghatározó szerepet, ezért nagyon fontos az ôket segítő pedagógus pozitív visszajelzése, megerősítő szerepe (Mesterházi és Szekeres, 2019). Mindemellett a pedagógusnak arra kell törekednie, hogy szabályozza, és szépen lassan csökkentse a külső motiválási folyamatban betöltött szerepét, mindezt úgy, hogy közben erősítse a tanuló önállóságát azért, hogy a szabályozás folyamata minél inkább belsőbbé váljon (Ryan és Deci, 2009). A motivációval kapcsolatban meghatározó tényező a pedagógus személyisége, mert amennyiben a motivátor szerepében elfogadó, empatikus, támogató, figyelmes, megértő személyiségjegyekkel bír, abban az esetben egy olyan pozitív érzelmi légkört teremt, amelyben a gyermekek bátrabban mernek visszajelezni, megnyilvánulni, érzéseiket kifejezni. Egy mosollyal kísért mozdulat bátorítást, elismerést nyújthat a gyermeknek, ugyanakkor egy szemöldökráncolás pedig figyelmeztető jelleggel bír (Réthy, 2003).

A játék funkcióörömöt nyújt, emellett számos pozitív tulajdonsággal rendelkezik, ezért a gyermek eredményes motiválásának elérése érdekében érdemes ezeket figyelembe venni, és a tanulás hatekony eszközeként felhasználni a pedagógiai folyamatban, mert így a tanuló észrevétlenül szerez információt, valamint mélyíti tudását. „A jó játékkal a monoton munkát felélénkíthetjük, izgalmával az órákat érdekesebbé tehetjük, osztályunk tanulóit szellemi frissességben tarthatjuk. A játék stabillá, ugyanakkor mozgékonnyá teszi az ismereteket. Megtanítja a gyerekeket a szerzett tudásanyag aktív, tevékeny alkalmazására, elkülönült anyagrészek rendszerbe illesztésére, a lényeg felismerésére, kombinációkra. Képessé teszi őket az ismeretek szokatlan helyzetekben való felidézésére és alkalmazására, tehát önálló, rendszerező gondolkodásra és tanulásra nevel." (Maár, 2009. 51.).

\section{A tanulásban akadályozott gyermekek tanulási folyamatainak jellemzői}

„A tanulási képesség azoknak a képességeknek a gyűjtófogalma, amelyek a gyermek fejlődésének folyamán egymással összefüggésben alakulnak ki: motoros, kommunikációs, emocionális, szociális, kognitív, kreatív és orientációs képességek." (Mesterházi és Szekeres, 2019. 63.). A tanulási képesség fejlődésében komoly funkciója van a kognitív folyamatoknak, az emocionális, szociális tényezőknek, a motivációnak, és a saját cselekvésből elsajátított tapasztalatoknak. A tanulási képesség alakulásának folyamatát különböző tényezők megzavarhatják, melyek következtében negatív irányú változás vagy lassulás léphet fel, így eredményezve annak átmeneti vagy tartós sérülését (Mesterházi, 1995).

A 2005/2006-os tanév során meghatározó előrelépés történt a hazai gyógypedagógiai diagnosztikát segitő alapfogalmak rendszerezésében, ami alapján a tanulási nehézségek három típusa különíthető el. A szakirodalom a megelốzés, a megsegítés és a várható eredmények tükrében mutatja be az adott csoportra legjellemzőbb tüneteket, az előidéző okokat és az előfordulási gyakoriságukat (Szabó, 2008). A tanulási nehézség, mint gyűjtőfogalom a következő típusokat foglalja magába: a tanulási elmaradás/gyengeség (átmeneti), a tanulási zavar (részleges), valamint a tanulási akadályozottság (átfogó és tartós). A tanulási nehézséggel küzdő tanulók tekintetében nagyon lényeges szempont fejlődési folyamatuk figyelemmel kísérése, egyéni fejlesztésük megvalósítása (Mesterházi és Szekeres, 2019). 
A tanulási nehézségek típusai közül a legsúlyosabb kategória a tanulásban akadályozottak csoportja, ami több képességterületre kiterjedő tartós, átfogó állapotot jelent. „A tanulásban akadályozottak csoportjába tartoznak azok a gyermekek, akik az idegrendszer biológiai és/vagy genetikai okokra visszavezethető gyengébb funkcióképességei, illetve a kedvezőtlen környezeti hatások folytán tartós, átfogó tanulási nehézségeket, tanulási képességzavart mutatnak." (Mesterházi, 1998. 54.). A tanulási akadályozottságra jellemző tünetek generalizáltan, a tanulási folyamat valamennyi területén átfogóan, súlyosan és tartósan jelennek meg, továbbá a tanulási problémák hátterében biológiai és/vagy genetikai tényezők, illetve kedvezőtlen környezeti hatások állnak. A tanulásban akadályozottak csoportjába tartoznak egyrészt azok a gyermekek, akiket a tanulási képességet vizsgáló szakértői és rehabilitációs bizottság a szakvéleményében enyhén értelmi fogyatékosnak (BNO kód F70) minősített. Ök létszámukat tekintve a tanköteles korú gyermekek 2-3\%-át alkotják. Továbbá a tanulásban akadályozottak csoportjába tartoznak azok a diákok is, akik a többségi általános iskolában súlyos tanulási nehézségekkel küzdenek, létszámukat tekintve ők a tanköteles korú népesség 12-13\%-át jelentik (Gaál, 2000).

A pedagógiai munka során a tanulásban akadályozott gyermekeknél problémák figyelhetők meg az egyensúlyészlelés, a taktilis-kinesztetikus észlelés, az auditív és vizuális észlelés, az emlékezet, a munkamemória, a kivitelezés-végrehajtás, a kommunikációs továbbá a szociális-emocionális területeken. Gondolkodási folyamataikra jellemző, hogy az intuitív-praktikus gondolkodásuk erősebb, mint a verbális-logikus gondolkodásuk, és a két folyamat közötti átmenet igen nehéz. A fejlődést akadályozó különböző okok kialakulási folyamata hosszú, hatásaik összeadódnak, és így különféle tanulási problémákhoz vezetnek. A tanulási folyamatban fellépó sikertelenségek és a kedvezőtlen szociális környezeti hatások a tanulási motiváció visszaeséséhez vezethetnek. Ilyenkor lényeges kideríteni az előidéző és folyamatosan ható okokat, azután pedig kedvező irányban szabályozni azokat, ezzel a tanulási akadályozottság részben megelőzhető, másrészt csökkenthető a súlyosságának mértéke (Mesterházi, 1995). A tanulásban akadályozott tanulókra jellemző, hogy elkerülik azokat a tanulási tevékenységeket, amelyek nagy erőfeszítést kívánnak meg tőlük, ennek következtében pszichikus funkcióik nem fejlődnek kellő mértékben. Az érintett gyermek tanulási képessége eredményesen fejleszthető, ha minél hamarabb a neki megfelelő támogatásban és különleges bánásmódban részesül, melynek során minden esetben hosszan elhúzódó fejlesztô tevékenységre és terápiára van szükség. Iskolai tanulmányaikat elkülönítetten gyógypedagógiai intézményekben vagy állapotuktól függően többségi iskolába integrálva végezhetik, azonban bármelyik intézménytípusban folytatják tanulmányaikat, fejlesztésük és megsegítésük kizárólag gyógypedagógiai kompetenciát igénylő folyamat (Gordosné, 2000).

A tanulásban akadályozott gyermekek tanulási képességük fejlesztéséhez speciális gyógypedagógiai megsegítést igényelnek, amennyiben mindezt a megfelelő időben és a számukra megfelelő módon megkapják, úgy tanulási problémáik csökkennek, életesélyeik jelentôsen javulnak. „A személyes élettörténetből és diagnosztikai eszközökkel megismerhető oki tényezők tudása mellett az egyén speciális nevelési szükségleteinek megállapítása és az ennek megfelelő nevelés együttesen eredményezheti a tanulásban akadályozott gyermekek minél kedvezőbb fejlődését.” (Mesterházi, 1995. 28.).

A tanulásban akadályozott gyermekek oktatásanevelése során nem érhetünk el olyan hatásos eredményt a szóban, történő emlékezetbe véső elsajátítással, mint a megtapasztalás útján, saját élményekbe ágyazottan megtanulandó ismeretekkel. Mindemellett rendkívül fontos a képességek fejlesztése, melyek során törekedni kell arra, hogy a 
képességek fejlesztése aprólékosan, elemeire bontott sűrű ismétléssel, gyakorlással járó tanulási folyamatban történjen. A tanulásban akadályozott gyermekek tanításakor alkalmazott szemléltető és tanulást támogató eszközök lényegében megegyeznek a többségi pedagógusok által használt eszközökkel, azzal a különbséggel, hogy ezeket a tanulási nehézséggel küzdő gyermekek hosszabb ideig használják. Az előzőekben említett eszközök mellett szükségessé válhat a tanulásban akadályozott gyermeket tanító pedagógus által olyan speciális eszközök elkészitése, amelyek az egyéni szükségleteknek megfelelően a megértést könnyítik. A munkát gyógypedagógiai asszisztens segítheti, azonban fontos figyelembe venni azt a szempontot, hogy a fejlesztést szolgáló eszközök mindig a gyermek sajátosságaihoz igazodjanak. A képességek fejlesztésében nagy hangsúlyt kell fektetni a közvetlen érzékelési tapasztalatokra és a tárgyi cselekvéses megismerésre, továbbá a gyógypedagógusnak törekednie kell arra, hogy a nevelési folyamatban az egész személyiséget érintő fejlesztés valósuljon meg. Fontos, hogy tudatosan és jól tervezetten azon munkálkodjon, hogy a tanulási, magatartási és viselkedési szokások minél célszerúbben és hatékonyabban alakuljanak, erősödjenek. Lényeges, hogy a gyógypedagógiai munka segítse a szemléletes képi gondolkodást, a legmegfelelóbb tanulási szokások kialakítását, a megismerési folyamatok tovább fejlesztését. A tanulási folyamatban fontos szempont, hogy a gyógypedagógus a tanuló állapotához mért legideálisabb tanulási tempót válassza meg, amit tovább segíthet a feladatok megfeleló, kisebb részekre bontása (Gordosné, 2004).

A tanulásban akadályozott tanulók készségeinek fejlődése a többségi társaikhoz képest lassúbb, időben elnyújtottabb periódus. A hátrányos környezettel rendelkezô gyermekek tanulási motivációja többnyire alacsony, nem kap szociális megerősítést, így a tanulás értékét számára az iskola képviseli. A tanulási motivációra nagymértékben hatást gyakorol az, ahogyan a pedagógus a tanulás folyamatát megsegíti és elismeri. Figyelembe kell vennie azt is, hogy a tanulásban akadályozott gyermekek a nevelójükhöz erősebben kötődnek, elismerését, megerôsitését jobban igénylik, mint többségi társaik, ebből adódóan számukra a pedagógus személye erőteljes motiváló erő (Józsa, 2007). A gyógypedagógiában a feldolgozás alappillérei a játékok és a játékos gyakorlatok, éppen ezért az oktatói-nevelói folyamatban való alkalmazásuk nagy hagyományokra tekint vissza. A komplexitás érdekében minél többféle pedagógiai módszer alkalmazása célszerü, amelyekkel a játékhoz kapcsolva oldott, felszabadult, elfogadó légkört teremthetünk (Czibere és Kisvári, 2006).

\section{A kutatás bemutatása}

A kutatás célja annak megismerése, hogy a játék milyen szerepet tölt be a vizsgálatban résztvevő pedagógusok munkájában, milyen pedagógiai módszereket alkalmaznak, illetve használják-e a játékot, a játékos lehetőségeket, mint módszertani eszközt? Amennyiben igen, akkor milyen gyakorisággal és milyen arányban teszik azt? A kutatásban olyan kérdésekre keressük továbbá a választ, hogy a pedagógusok mely célok elérése érdekében használják a játék adta lehetőségeket, milyen eszközökkel és munkaformában valósítják meg ezen célok elérését?

A kutatási kérdéseinknek megfelelően az alábbi hipotéziseket fogalmaztuk meg:

1. A gyógypedagógusok az alsó és felső tagozaton egyaránt gyakrabban használják és több időt fordítanak a játékra, játékos tevékenységre, mint a többségi oktatásban résztvevő pedagógusok.

2. A gyógypedagógusok gyakrabban használnak saját készítésú eszközöket a tanórai játékokban, mint a többségi pedagógusok.

3. A többségi pedagógusok didaktikai játékban használt eszközeik közül az infokommunikációs technológián alapuló eszközök a legnépszerúbbek. 
A kutatás Szabolcs-Szatmár-Bereg és HajdúBihar megyében valósult meg 2021. januárjában. A célcsoportot alkotó személyek a tanulásban akadályozott gyermekek tanításában résztvevő gyógypedagógusok és többségi általános iskolában tanító pedagógusok voltak. A vizsgálatban kvantitatív kutatási módszert alkalmaztunk, mely egy saját összeállítású kérdőívet jelentett.

Célirányosan juttattuk el a pedagógusoknak a kérdőívet, a részvétel önkéntes volt, az adatgyüjtés anonim módon, önkitöltős formában történt. Az „illetéktelen” kitöltések elkerülése érdekében kizárólag öt általános iskola és öt gyógypedagógiai nevelési-oktatási intézmény osztályban tanító pedagógusai részére vált elérhetôvé a kérdőív az érintett intézmények vezetőinek segítségével. Az intézményvezetőktől kapott levelezôlista alapján az ott dolgozó pedagógusok, gyógypedagógusok közvetlenül, személyes e-mail címükre kapták meg a kutatásban való részvételre vonatkozó felkérést, melynek eredményeképpen 102 fö töltötte ki a kérdőívet. A beérkezett kérdőívek mindegyike értékelhető volt, néhány esetben fordult csak elö, hogy az utolsó kérdés megválaszolatlan maradt, így ennek figye-lembevételével történt az eredmények értékelése. A kérdéseket egyesével elemeztük, me- lyeket vizsgáltunk a teljes mintára vonatkozóan, illetve intézménytípus (gyógypedagógiai nevelésioktatási intézmény, többségi általános iskola) és tagozat (alsó, felső) szerinti csoportbontásban is, statisztikai próbákat nem alkalmaztunk a kis elemszám miatt, de a csoportok közötti különbség így is látható. A többségi általános iskola alsó tagozatán tanító pedagó-gusok csoportját a „többs. alsó”, a többségi általános iskola felső tagozatán tanító tanárok csoportját a „többs. felső”, a tanulásban akadályozottak általános iskolájának alsó tagozatán tanító pedagó-gusok csoportját a „gyógyp. alsó”, a tanulásban akadályozottak általános iskolájának felső tagozatán tanító pedagógusok csoportját pedig a „gyógyp. felső” rövidített kifejezésekkel jelöljük. A pedagó-gusok jellemzőit az 1. táblázat mutatja be.

A kitöltő pedagógusok 25,5\%-a (26 fő) általános iskola alsó tagozatán tanító, 24,5\%-a (25 fö) általános iskola felső tagozatán tanár, 25,5\%-a (26 fö) gyógypedagógiai nevelési-oktatási intézmény tanulásban akadályozottak tagozatának alsó évfolyamán gyógypedagógus, illetve 24,5\%-a (25 fő) gyógypedagógiai nevelési oktatási intézmény tanulásban akadályozottak tagozatának felső évfolyamán gyógypedagógus (1. ábra).

1. táblázat: A válaszadók nem és életkor szerinti megoszlása, valamint a pedagógusi pályán eltöltött ideje. (N=102) (fö; \%). Forrás: Szerző́k.

\begin{tabular}{|c|c|c|c|c|c|}
\hline \multicolumn{6}{|c|}{ Életkor } \\
\hline & 21-29 év & 30-44 év & 45-59 év & \multicolumn{2}{|c|}{60 év felett } \\
\hline & $4,9 \%$ (5 fö) & $35,3 \%$ (36 fö) & $49 \%$ (50 fö) & \multicolumn{2}{|c|}{ 10,8\% (11 fö) } \\
\hline \multicolumn{6}{|c|}{ Nem } \\
\hline Férfi & $1 \%$ (1 fö) & $4,9 \%$ (5 fö) & $4,9 \%$ (5 fö) & \multicolumn{2}{|c|}{$1 \%$ (1 fö) } \\
\hline Nö & 3,9\% (4 fö) & $30,4 \%$ (31 fö) & $44,1 \%$ (45 fö) & \multicolumn{2}{|c|}{$9,8 \%$ (10 fö) } \\
\hline \multicolumn{6}{|c|}{ A pedagógusi pályán eltöltött idő } \\
\hline & $\begin{array}{c}\text { kevesebb, mint } \\
2 \text { év }\end{array}$ & 2-9 év & 10-19 év & 20-29 év & $\begin{array}{c}\text { több, } \\
\text { mint } 30 \text { év }\end{array}$ \\
\hline & $2,9 \%$ (3 fö) & 10,8\% (11 fö) & $29,4 \%$ (30 fö) & $28,4 \%$ (29 fö) & $28,4 \%$ (29 fö) \\
\hline
\end{tabular}


1. ábra. A válaszadók munkaköre és intézménytipusának megoszlása $(N=102$ fö). Forrás: Szerző̉k.

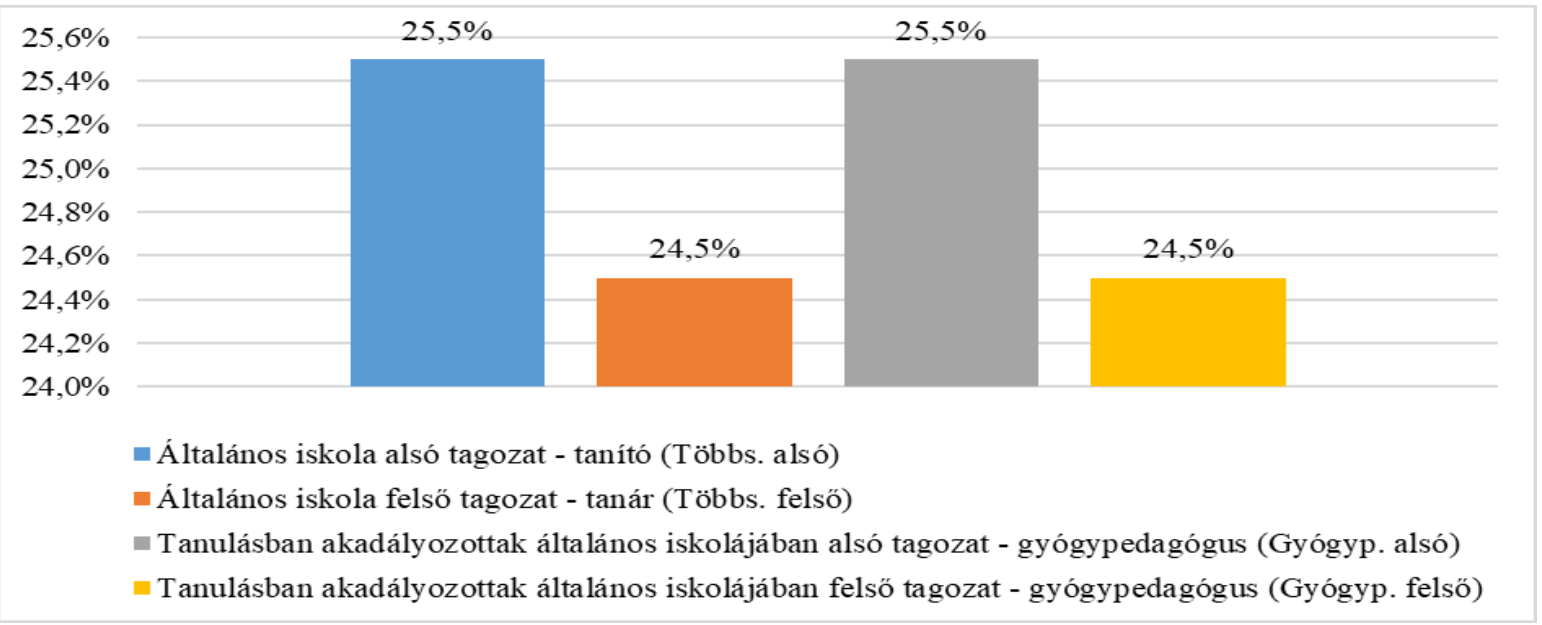

A válaszadó pedagógusok által alkalmazott módszerek és kedveltségük

A kitöltők munkájában leggyakrabban alkalmazott pedagógiai módszerek vizsgálatához a következő válaszlehetőségeket adtuk meg: előadás, magyarázat, megbeszélés, szemléltetés, kérdezés, projektmódszer, kooperatív oktatási módszer, játék, szerepjáték, szimuláció, vita, tanulói előadás, ellenőrzés, differenciálás. A felsorolt alternatívákhoz egytől négyig terjedő skálán válaszokat adtunk meg, melyben a „soha” válasz esetén egyes érték, a „ritkán” jelöléshez kettes érték, „gyakran” válasz esetében a hármas érték, a „mindig” válaszhoz pedig a négyes érték tartozott a kiértékelés folyamán.

A válaszadók körében a leggyakrabban alkalmazott módszerek a szemléltetés (3,51), a differrenciálás (3,38), a magyarázat $(3,30)$, a kérdezés (3,29, az ellenőrzés (3,29), a megbeszélés $(3,26)$ és a játék $(3,09)$ voltak. A vizsgálatban résztvevők ritkán vagy egyáltalán nem alkalmazzák a tanulói előadás $(2,03)$ és a vita $(1,97)$ módszerét (2. ábra).

2. ábra. Pedagógiai módszerek alkalmazása a válaszadók körében ( $N=102$ fó). Forrás: Szuerzők.

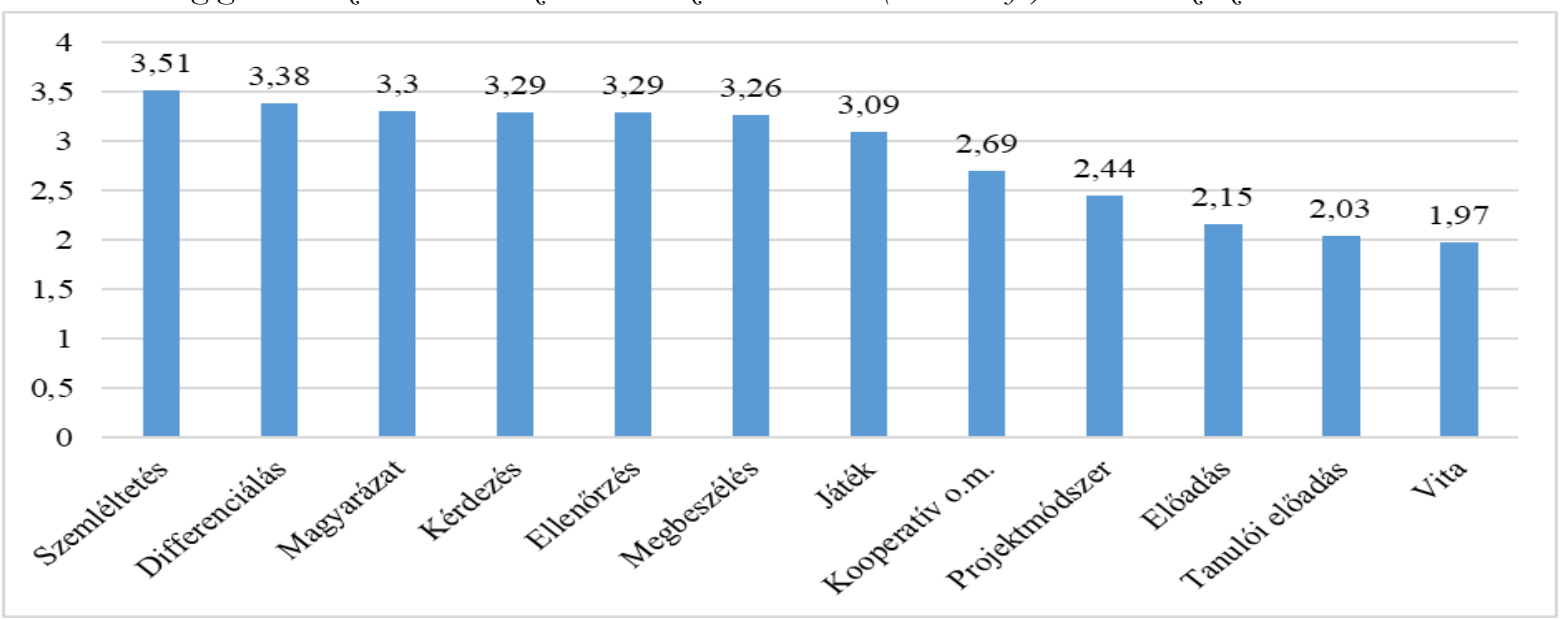


A különböző pedagógiai módszerek használatának gyakoriságát tekintve a csoportok közel azonos arányban vélekedtek egy-egy technikáról, de egyes módszerek esetében nagyobb eltérés volt megfigyelhető a négy pedagógusi csoport között (3. ábra). Ilyen eltérés mutatkozott a differenciálás, a játék, az előadás, a vita és a tanulói előadás esetében. A kitöltők közül a gyógypedagógusok - alsó és felsô tagozaton egyaránt - jóval hangsúlyosabbnak tartották a differenciálás (3,69 és 3,52), illetve a játék (3,34 és 3,2) módszerét, mint a többségi oktatásban résztvevő pedagógustársaik. Ennek ellenkezője figyelhető meg az előadás, vita, tanulói előadás módszereiben, mert azokat az eljárásokat pedig a többségi pedagógusok alkalmazzák sokkal gyakrabban a gyógypedagógiában dolgozókhoz képes, aminek hátterében az eltérô gyermeki képességek állhatnak. A vizsgálatban résztvevô gyógypedagógusok leggyakrabban a differenciálás módszerét alkalmazzák. A válaszadók közül 32 gyógypedagógus mondta azt, hogy mindig alkalmazza a differenciálás módszerét, ami a teljes minta 31,36\%-át teszi ki, ezzel szemben a tanítók, tanárok részéről 15 fô volt, aki ugyanezt válaszolta, ők a minta 14,7 \%-át jelentik. Az arányokat tekintve elmondható, hogy a kutatásban résztvevők közül a gyógypedagógusok kétszer annyian használják munkájukban mindig ezt az eljárást, mint a többségi iskolában tanító pedagógusok. Az eltérés abból adódhat, hogy a gyógypedagógiában a hatékony fejlődés alapja az egyéni sajátosságok figyelembevétele, mert nincs két egyforma tanuló, a tanulásban akadályozott tanulók esetében pedig jobban megmutatkoznak a különbségek és még szembe tűnőbbek. A válasz-adó gyógypedagógusok érzékenyek a tanulóik egyéni különbségeit illetően, és a munkájuk során figyelembe veszik azokat, így tanulóik egyéni sajá-tosságaira alapozva fejlesztik őket a legoptimálisabb szint elérése érdekében. Ez alapján megfelelnek annak a 2011. évi, nemzeti köznevelésről szóló CXC. törvény 3. § (6) pontja által megfogalmazott elvárásnak, ami a köznevelés kiemelt feladatának tekinti a sajátos nevelési igényű tanulók speciális igényeinek figyelembevételét, és egyéni képessé-geikhez igazodó legeredményesebb fejlődésük elősegítését.

A játék módszerét vizsgálva a differenciálás módszerével megegyező eltérés figyelhető meg szintén a gyógypedagógusok javára. A játék módszertani alkalmazásának gyakoriságában az alsó tagozaton tanító gyógypedagógusok 3,34 értéket mutattak, a felső tagozaton tanító gyógypedagógusok 3,20 értéket. Velük szemben a többségi oktatásban alsó tagozaton a tanítók eredménye 3,00 volt, a felső tagozaton tanító tanárok értéke pedig a legkisebb, 2,84 értéket mutatta (3. ábra).

3. ábra. Pedagógiai módszerek alkalmazása a válaszadók körében, csoportbontásban (N=102 fö). Forrás: Szuerzők.

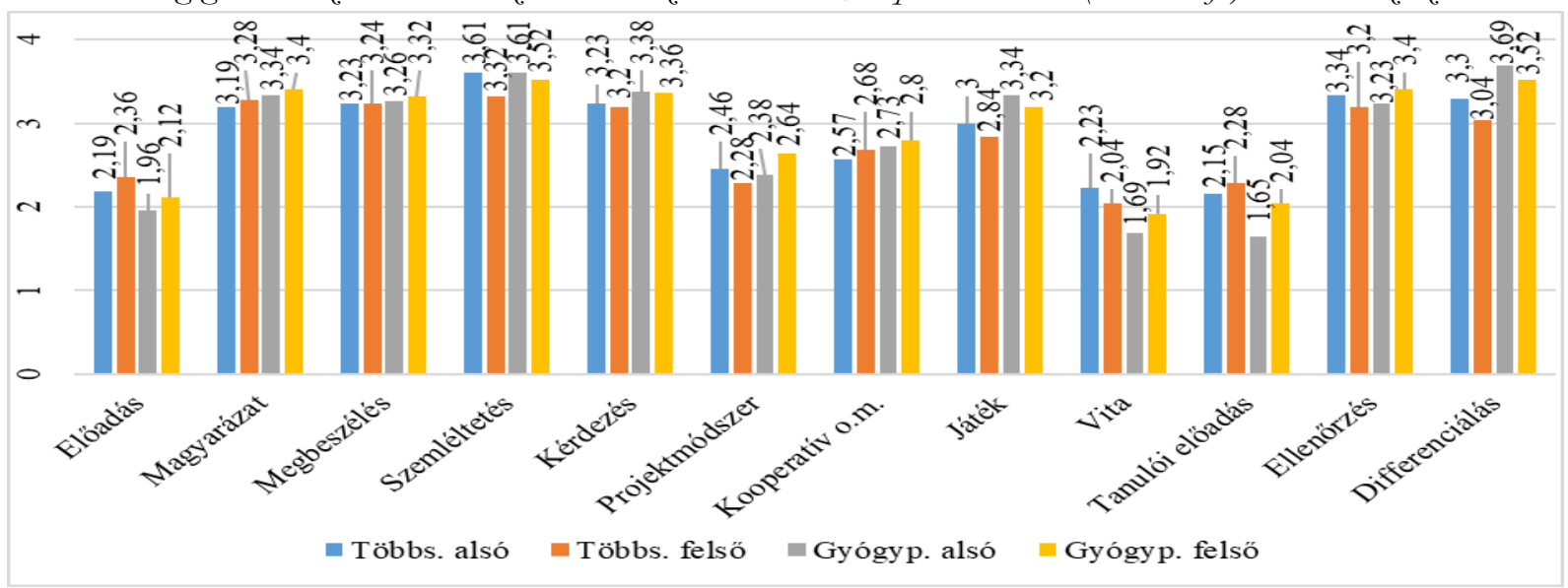


A vizsgálatban résztvevők a munkájuk során alkalmazott módszerek közül legtöbben (27 fő) a differenciálás módszerét tartották a leghatékonyabbnak, majdnem ugyanennyi, 26 fô vélekedett úgy, hogy a szemléltetés eszközét tartja hatékonynak. Ez a két csoport összesen a válaszadók 52\%-át jelentik. Ezt követte a kooperatív módszer, amit 15 fó $(14,7 \%)$ tartott hatékonynak, illetve a játék módszere, amit 14 fô (13,72\%) jelölt a leghatékonyabb eszköznek. A fennmaradó közel 20\%-ba az alábbi eljárások kerültek: a projektmódszert 7 fó, a magyarázatot 6 fó, a megbeszélést 4 fó, az ellenőrzés, a kérdezést és a vitát is 1-1 fô adta meg válaszként (4. ábra).

A csoportok bontását tekintve a differenciálás módszerét fóként a gyógypedagógusok (17 fö) jelölték meg a 10 többségi pedagógussal szemben, így az előző kérdés eredményével összhangban és azt alátámasztva elmondható, hogy a gyógypedagógusok közel kétszer annyian alkalmazzák a differenciálás módszerét, és ezt tartják a leghatékonyabbnak. A szemléltetés módszerét ugyanannyi gyógypedagógus (13 fó) és ugyanannyi többségi pedagógus (13 fó) tartja a leghatékonyabbnak. Ezeket követi a kooperatív technika, amit a tanítók csoportja tartotta a leginkább hatékonynak, a 15 válaszadóból 6 fó volt tanító, a 3 alsós gyógypedagógussal szemben. A játék 14 fő álláspontja szerint a legcélravezetőbb pedagógiai módszer, ezzel a negyedik helyen szerepel a kitöltők körében. A válaszok 8 gyógypedagógustól és 6 többségi pedagógustól származnak, a legtöbben alsós gyógypedagógusok.

A vizsgálat arra is kitért, hogy a pedagógusok szerint a tanulók körében mennyire népszerű a játék, mint módszer. Nagyon meggyőző eredmény született. A válaszadók 68,60\%-a, azaz 70 fö vélekedett úgy, hogy diákjai szerint a játék a legkedveltebb pedagógiai módszer (5. ábra). A következő módszereket jelölték még meg: a kooperatív oktatási módszer ( 9 fó), a szemléltetés (8 fö), a megbeszélés (5 fö), a projektmódszer (4 fô), a tanulói előadás (3 fô), a magyarázat (1 fố), a kérdezés (1 fő) és az ellenőrzés (1 fö), de ezek mind $10 \%$ alatti eredmények voltak

4. ábra. A kutatásban rész̨tvevö pedagógusok által leghatékonyabbnak tartott módszerer ( $N=102$ fö). Forrás: Szerzöók.

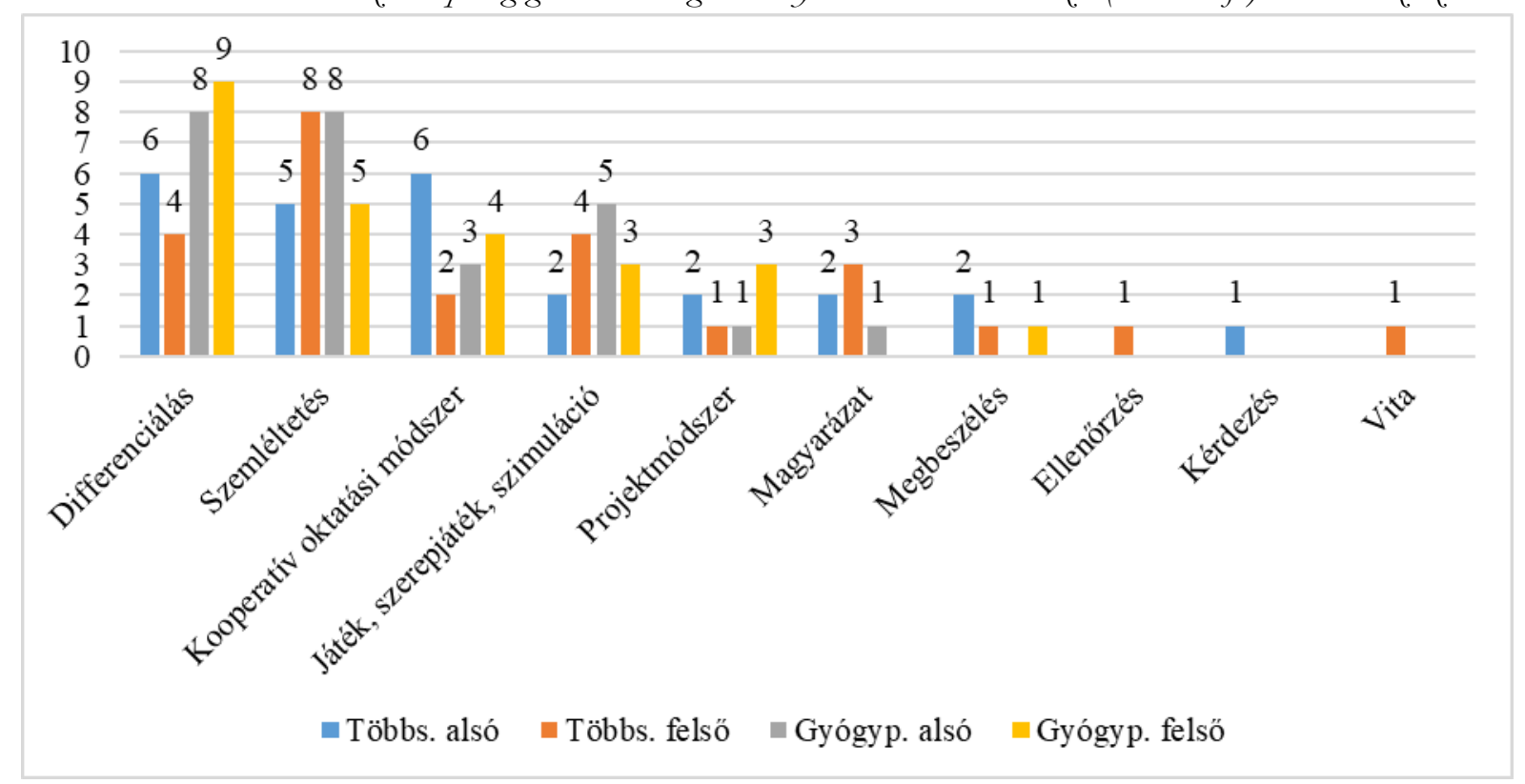


5. ábra. A kutatásban résztvevô pedagógusok véleménye szerint a diákok körében legkedveltebb pedagógiai módszer $(\mathrm{N}=102$ fö). Forrás: Szerzölk.

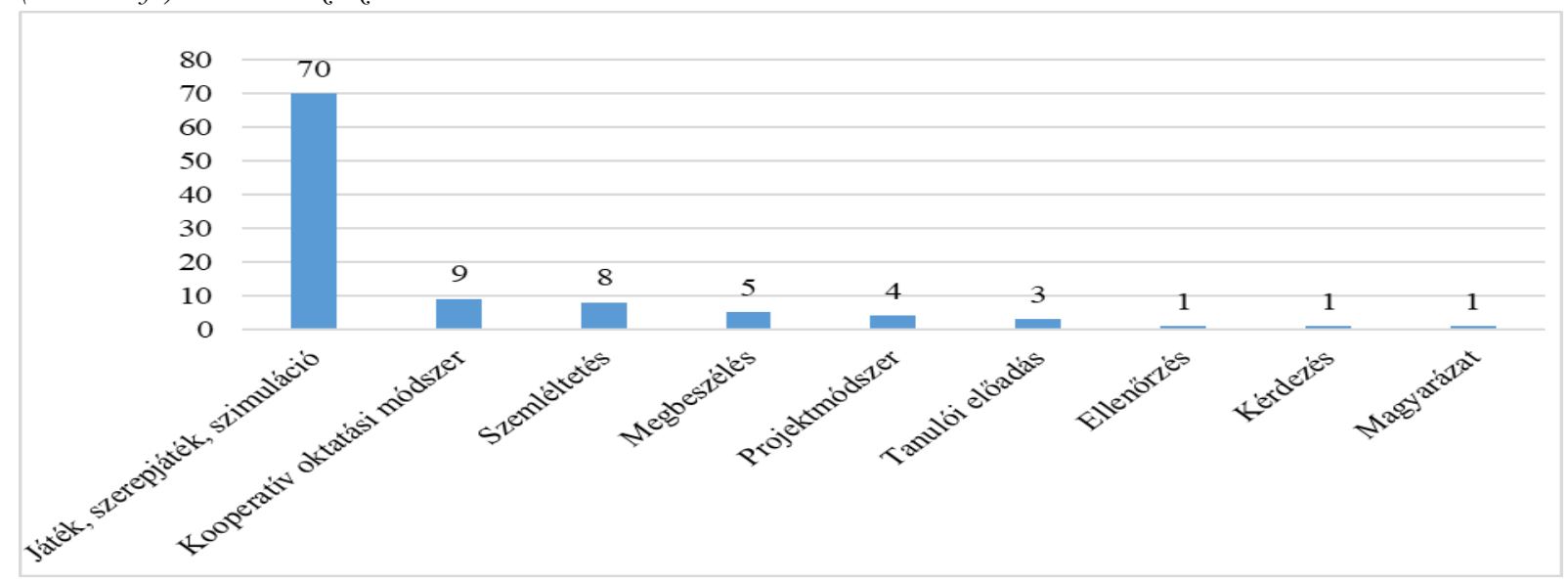

\section{A játék használatának jellemzői a tanítási órákon}

A pedagógusok játékhasználatának gyakoriságát tekintve a válaszadók 27,44\%-a (28 fó) minden órán alkalmazza a játékot, míg 50\% (51 fö) naponta néhány órán, és 20,58\% (21 fö) pedig hetente. Ritkábban, mint hetente a válaszadók 1,96\%-ára (2 fő) jellemző.

A csoportok szerint, az alsó tagozaton tanító gyógypedagógusok $(3,50)$ használják leggyakrabban a játékot, többségük minden órán. Öket követik a felső tagozaton tanító gyógypedagógusok $(3,24)$, akik szintén minden órán vagy naponta néhány órán használnak játékot. A többségi iskolában dolgozó tanítók $(2,80)$ ritkábban használják, mert ők többségében azt válaszolták, hogy naponta néhány órán vagy hetente alkalmazzák azt, és a legritkábban a többségi tanárok használják (2,56), akiknek a fele úgy nyilatkozott, hogy hetente, illetve 2 fő válaszolta, hogy ritkábban, mint hetente használ játékot. Összességében tehát a játék, mint módszer a válaszadók túlnyomó többségénél, 77,42\%-nál (79 fö) naponta jelen van az oktatóinevelői munkában (6. ábra).

6. ábra. A kutatásban rész̨tvevö pedagógusok játékhasználatának gyakorisága (N=102 fö). Forrás: Szerzök.

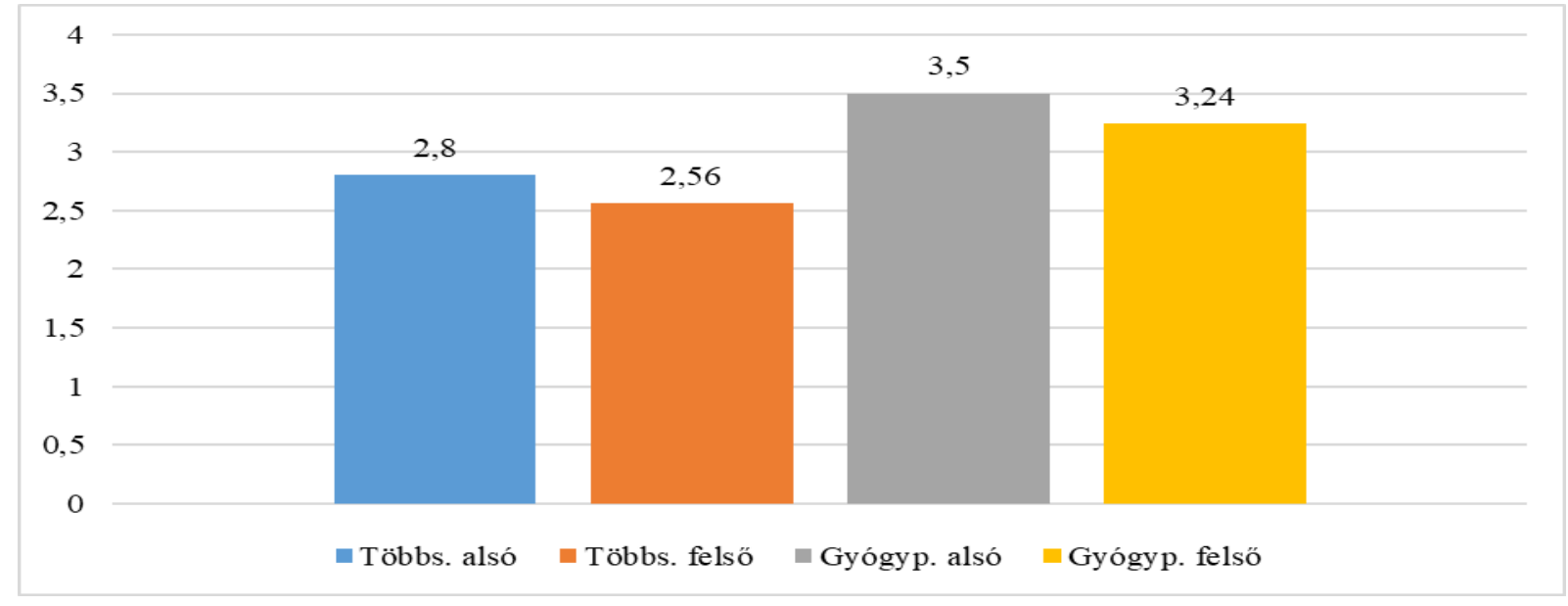


Vizsgálatunkban arra is kitértünk, hogy a játék az óra mely szakaszában jelenik meg. A válaszlehetőségek között az alábbi öt alternatíva szerepelt: „bevezető rész”,” célkitűzés”, „fő rész”, „összefoglalás”, „óra zárása”, ,jutalmazás”. A felsorolt alternatívákhoz gyakoriságot mutató válaszok kerültek, melyek skálaértékkel párosítva a következők: „soha” válasz esetén egyes érték, „ritkán” jelöléséhez kettes érték, „gyakran” válasz esetében hármas érték, a „mindig” válaszhoz pedig a négyes érték tartozott. A kutatás résztvevői az óra zárása, jutalmazás részt 3,06-re, a bevezetô részt 3,02-re, az összefoglalás részt 2,80-ra, a fó részt 2,75-re, a célkitűzést pedig 2,20-ra értékelték (7. ábra).

Összességében, az óra minden részében megjelenik a játék, de főképp a bevezető részben, az óra zárásában és a jutalmazásban dominál. Továbbá megfigyelhetô, hogy a többségi felsős tanárok átlaga szinte minden órarészletnél a legalacsonyabb értéket mutatja, tehát a többi csoporthoz képest ritkábban használják a játékot a tanítási órán.
Rákérdeztünk arra is, hogy a kitöltők a tanítási órán mennyi idôt szánnak a játékra. A kérdésre a pedagógusok szabadon megadhatták a választ percben kifejezve, és bár ennél a kérdésnél konkrét idôt kértük a pedagógusoktól, ôk gyakran intervallumot adtak meg. A beérkezett válaszok öt perctôl harmincöt percig terjedtek az időskálán. Az öt percet 9 fő válaszolta, ezt követően hét perctôl tíz percig 56 fó, a tizenöt percig 23 fó, húsz percig 11 fö adott meg időtartamot, míg 1-1 fő huszonöt, harminc és harmincöt percet írt (8. ábra). A csoportokat vizsgálva megállapítható, hogy a többségi pedagógusok inkább az öt és tíz perc közötti intervallumot jelölték meg, a gyógypedagógusok többsége pedig a tíz és húsz perc közöttit. 1-1 fő alsós gyógypedagógus úgy nyilatkozott, hogy huszonöt, harminc, illetve harmincöt percet szán egy tanórán belül játékra. Mindezek alapján a vizsgálatban résztvevő gyógypedagógusok nemcsak gyakrabban alkalmazzák a játékot, de közel kétszer annyi időt fordítanak rá egy tanítási órán belül.

7. ábra. A tanitási óra részeiben a játék alkalmaz̃ása, gyakorisága (N=102 fó). Forrás: Sžeržók.

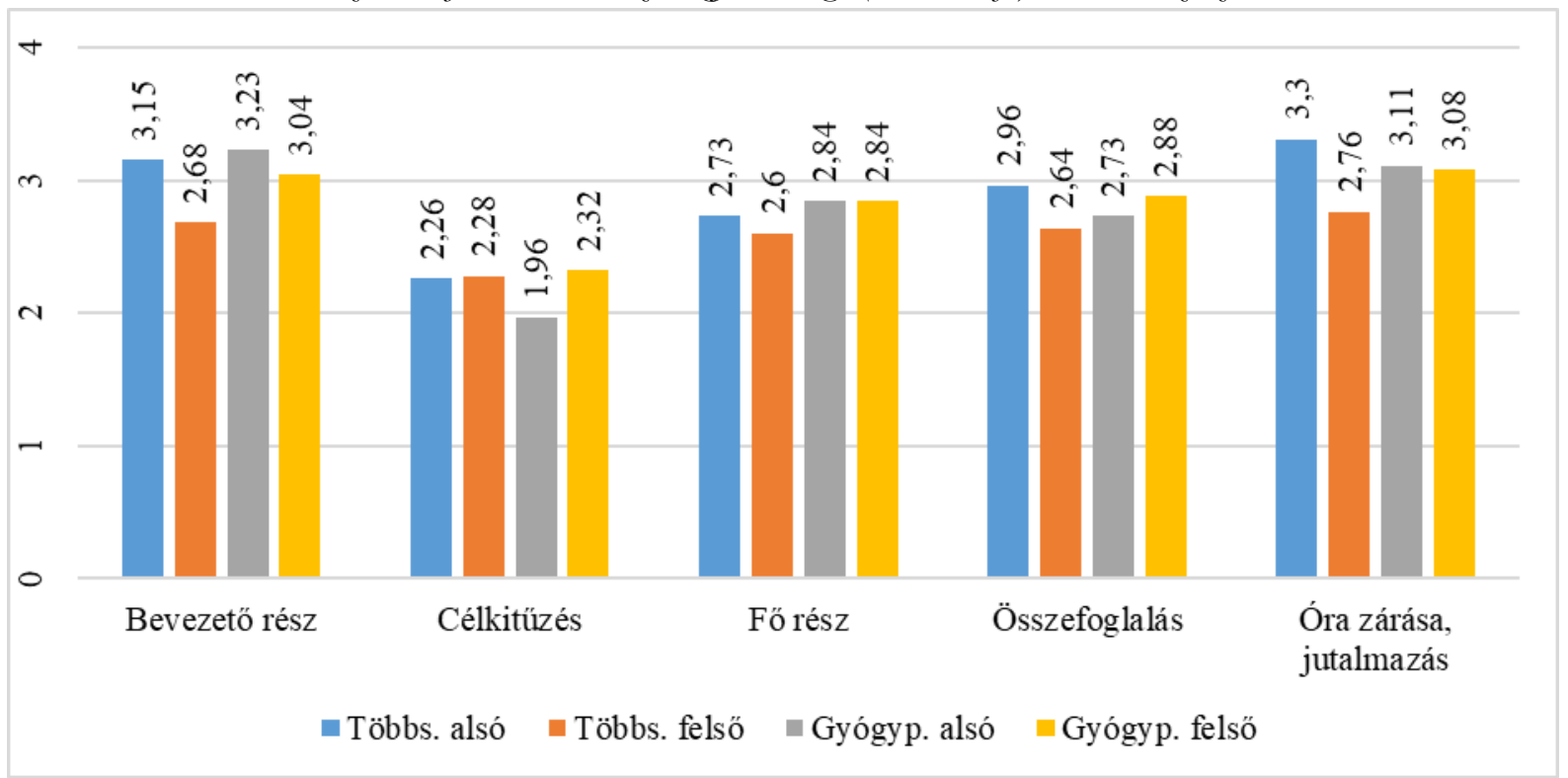


8. ábra. Egy tanitási órán belül a játékra forditott idö (N=102 fö). Forrás: Szerzöke.

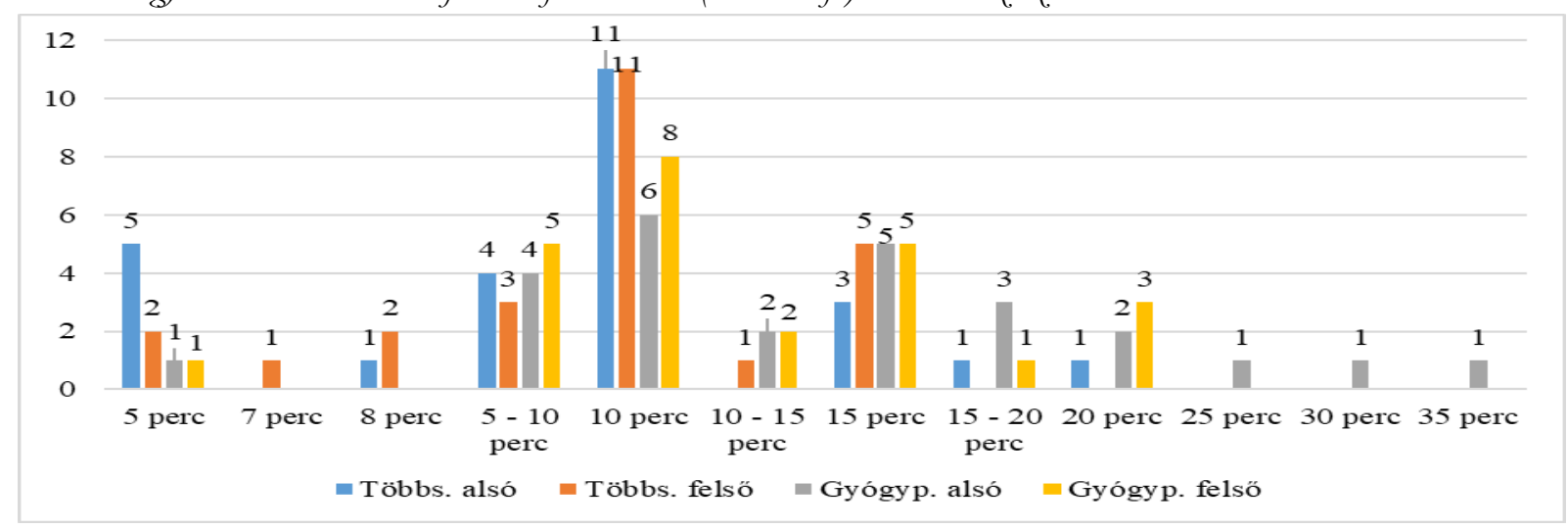

A vizsgálatban résztvevők véleménye azt igazolja, hogy leggyakrabban motiválás $(3,28)$ céljából alkalmazzák a játékot, ami teljes mértékben megegyezik az előző megállapítással, miszerint a játéknak jelentős motiváló ereje van. A játékot gyakran alkalmazzák még a tanórára hangolás $(3,12)$, a jutalmazás $(3,11)$, a képességek fejlesztése $(3,08)$, a monotonitás megtörése $(3,05)$, a cselekedtetés $(3,05)$ és a gyakorlás $(3,01)$ célok elérése érdekében. A pedagógusok legkevesbé az új ismeretek feldolgozása $(2,48)$ és a tanult ismeretek számonkérése $(2,44)$ érdekében alkalmaznak játékot.

A csoportok közötti eltéréseket vizsgálva megállapítható, hogy a gyógypedagógusok jóval gyakrabban használják a játékot a képességek fejlesztésére, új ismeretek feldolgozására és a személyiség formálására. A képességek játékkal való fejlesztését az alsós gyógypedagógusok $(3,34)$ és a felsős gyógypedagógusok $(3,20)$ jóval hangsúlyosabbnak tartották, a többségi alsós $(3,03)$ és felsős $(2,76)$ pedagógussal szemben. Szintén megfigyelhető az eltérés az új ismeretek feldolgozása esetén alkalmazott játékoknál, ugyanis ezt a gyógypedagógusok alsó tagozaton 2,50-re, felső tagozaton 2,92-re értékelték, míg ugyanezt a többségi alsós tanítók 2,26-ra, a felsős tanárok pedig 2,24-re. A jutalmazás tekintetében pedig a tanítók csoportjának eredménye tér el kiugróan (3,34), vagyis ők jóval gyakrabban alkalmazzák a játék módszerét elismerés céljából (9. ábra).

9. ábra. Célok, amelyek elérésébez alkalmazzák a játékot a résztvevö pedagógusok (N=102 fö). Forrás: Szerzốk.

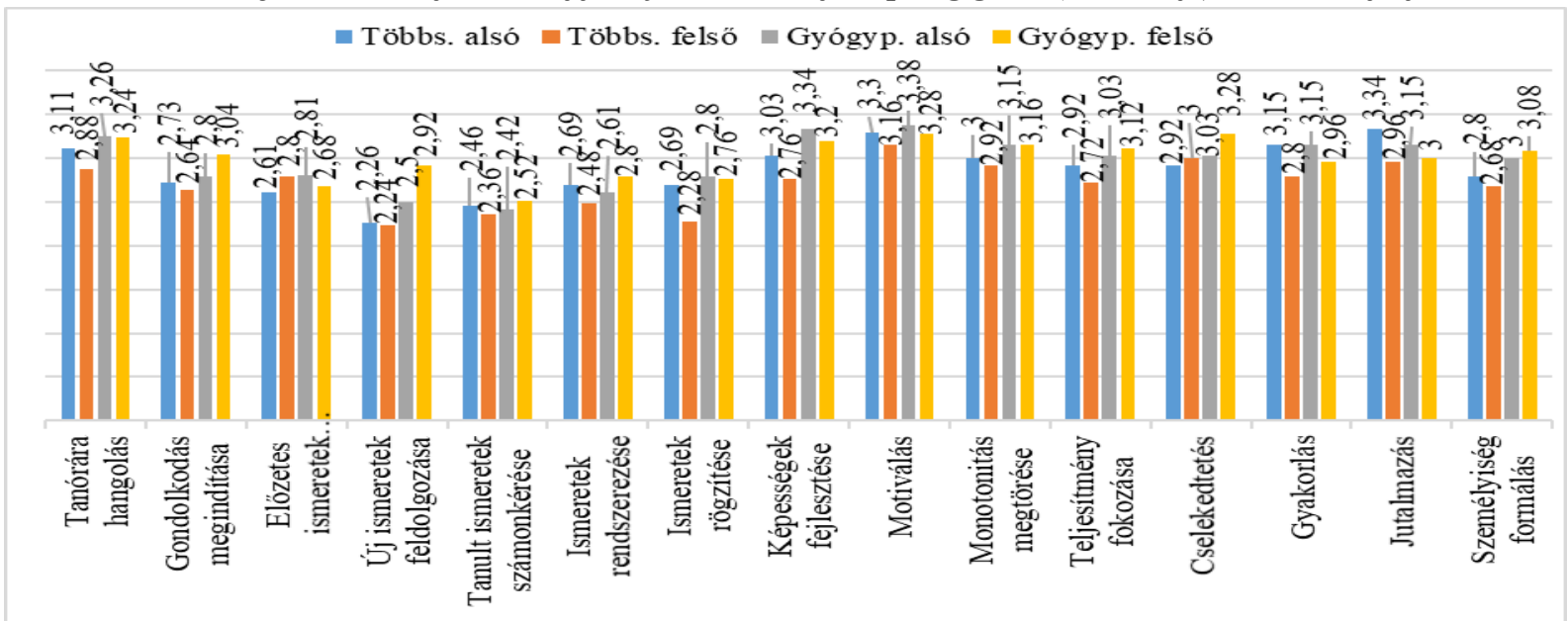


Arra is rákérdeztünk, hogy a játék során mely munkaformák a jellemzőbbek. A didaktikai játékban előforduló munkaformák gyakoriságának vizsgálatához felsoroltuk az összes lehetséges alternatívát: egyéni, páros, tanulócsoport, tanulócsoportok közötti, egész osztályt bevonó munkaforma, s ezeket az egyes értékű „egyáltalán nem” válaszlehetőségtől a négyes értékű „minden alkalommal" válaszig értékelhették a kitöltők. A kapott eredmények azt mutatták, hogy az órai játék során leggyakoribb a páros munkaforma (2,99), ezt követi az egész osztály $(2,97)$, majd a tanulócsoport $(2,79)$, egyéni $(2,77)$ és végül a tanulócsoportok közötti játékok $(2,43)$. Összességében, a módszertani játék valamennyi munkaformában szinte kiegyenlítetten jelen van, ebből adódóan változatos munkaformákra ad lehetőséget.

A munkaköri csoportokat elemezve megállapítható, hogy a felső tagozatban tanító gyógypedagógusok a többiekhez képest ritkábban használják az egyéni munkaformát a játékok során, továbbá a gyógypedagógusok körében szintén ritkábban használt munkaforma az egész osztály bevonásával történő játék. Az alsós gyógypedagógusok a tanulócsoportok közötti játékot értékelték a legalacsonyabbra $(2,15)$, aminek háttérében valószínúleg a versengés elkerülése állhat (10. ábra).

A tanórai játékok során használt eszközök és azok előfordulási gyakoriságának vizsgálatához számos elemet soroltunk fel, melyekhez gyakoriságot mutató kifejezések tartoztak egytől négyig terjedő skálán. A pedagóguscsoportok didaktikai játékban való eszközhasználatát vizsgálva megállapítható, hogy a többségi pedagógusok leginkább az interaktív táblát és az IKT eszközöket részesítik előnyben, míg a gyógypedagógusok csoportja fôképp a szemléltető eszközöket és a saját készítésű eszközöket alkalmazza, illetve a tankönyv kivételével valamennyi, általunk felsorolt eszközt is gyakran használ (11. ábra). A pedagógusok válaszaiból azt a következtetést vonhatjuk le, hogy a digitalizáció uralta világunkban a kutatásban résztvevő többségi pedagógusok a didaktikai játékban is nagyobb teret engednek az ilyen jellegú eszközöknek, háttérbe szorítva a hagyományos eszközöket.

10. ábra. A játék módszertani alkalmazása során elóforduló munkaformák $(N=102$ fó). Forrás: Szerzók.

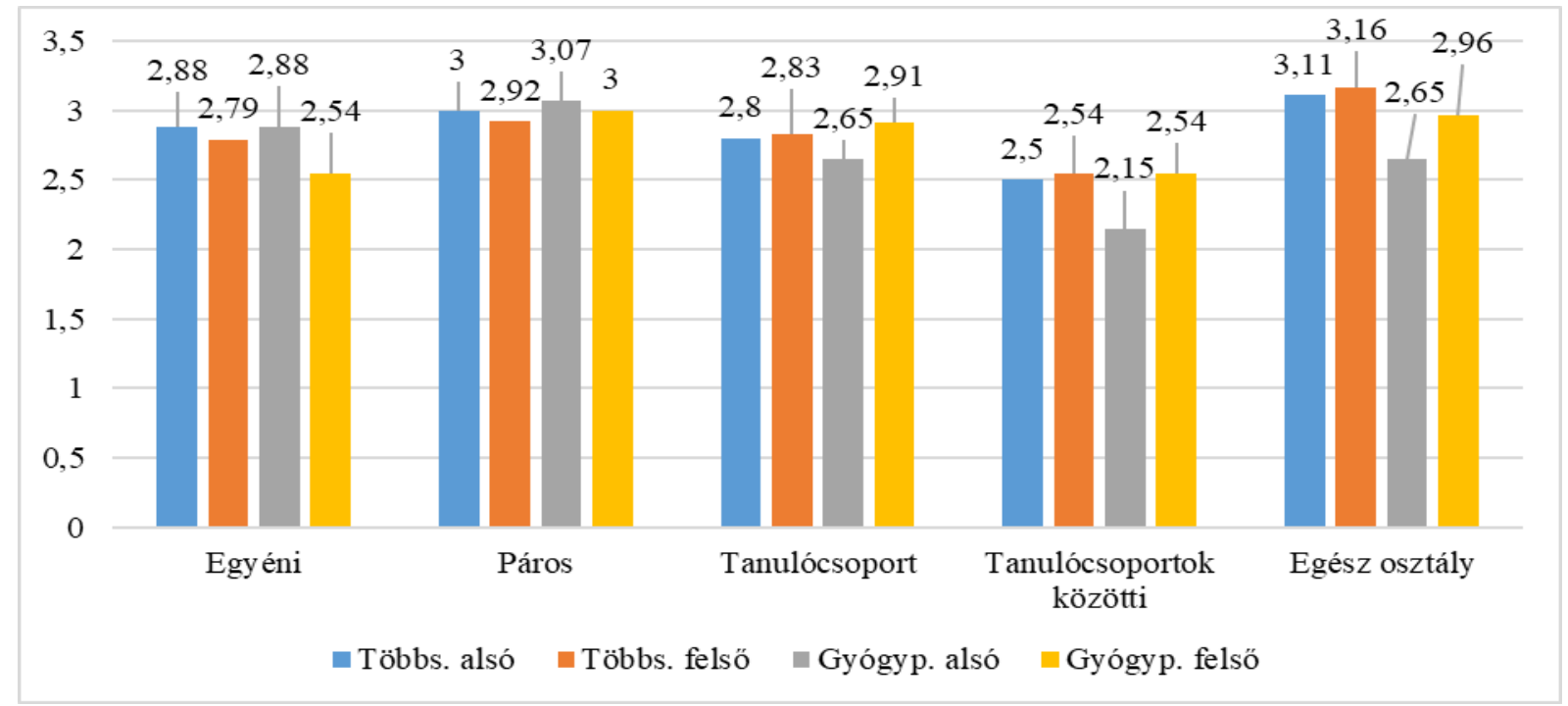


11. ábra. A játék módszertani alkalmazáááboz használt es₹közzök $(N=120$ fó). Forrás: Szurzók.

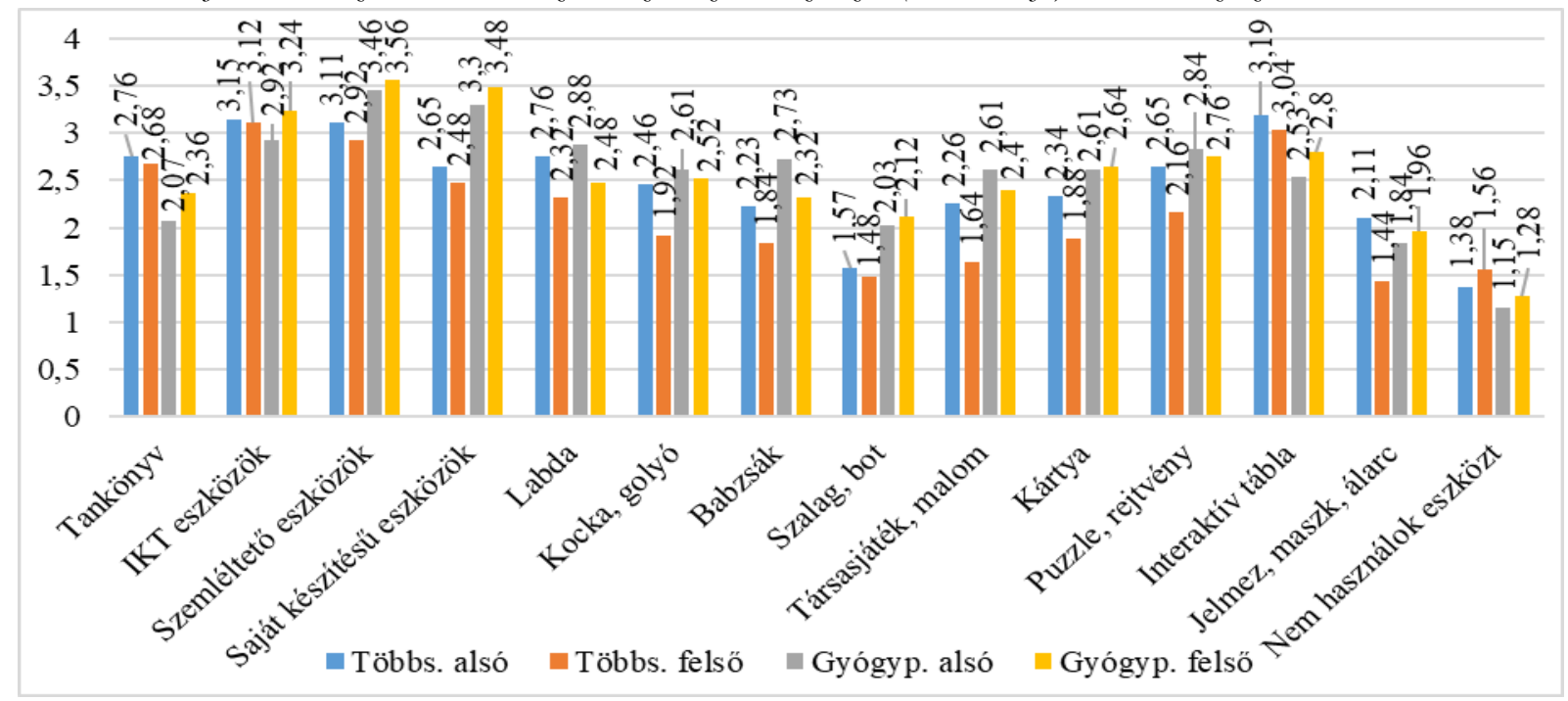

Ezzel szemben a gyógypedagógusok a tanulásban akadályozott tanítványaik speciális szükségleteikre alapozva a pedagógiai eszközöket igyekeznek kiegészíteni, hogy ezekkel a speciális, egyénre szabott fejlesztést hatékonyan megvalósíthassák. Ezt a megállapítást támasztja alá a saját készítésű eszközök alkalmazásának tekintetében született jelentôs eltérés, mely szerint az alsó tagozaton tanító gyógypedagógusok 3,30 értéket, a felsô tagozaton tanítók pedig 3,48 értéket mutattak. A többségi pedagógusok esetében az alsó tagozaton tanítók válaszai 2,65 értéket, a felső tagozatos tanároké pedig 2,48 átlagot jelentettek.

\section{A pedagógusok véleménye a játékról}

A játékkal kapcsolatban nyolc megállapítást fogalmaztunk meg (12. ábra), ahol minden állitáshoz egytől négyig terjedő skálaértékek tartoztak: az egyes érték az „egyáltalán nem ért egyet”, a négyes érték pedig a "teljesen egyetért” válaszlehetőséget jelentette. A megállapítások a játék egyes pozitívumait emelték ki, a válaszadók döntô többsége valamennyi állítást elfogadta vagy azzal teljes mértékben egyetértett. A csoportokat vizsgálva három esetben mutatkozott jelentôsebb különbség, mégpedig az alsó évfolyamon dolgozó gyógypedagógusok tekintetében, akiknek válaszai a másik három csoporttal szemben sokkal pozitívabb megnyilvánulást, eredményt mutattak a játék differrenciálásban való hatékony alkalmazásában $(3,83)$, a játékkal történő hatékony tananyagtartalom elsajátításában $(3,46)$ és a játék iskolával kapcsolatos szorongásoldásában $(3,88)$. Valószínú, hogy a gyógypedagógusok gyakrabban találkoznak szorongó gyermekkel, gyakrabban alkalmazzák a differrenciálás módszerét, éppen ezért nagyobb jelentóséget is tulajdonítanak ezekben a helyzetekben egy-egy hatékonyan alkalmazható eszköznek, ez esetben a játéknak. Érthető a gyógypedagógusok effajta rendkívül pozitív szemlélete, mert a gyógypedagógiai megsegítést igénylő gyermekeknek erre fokozottan szükségük van. 
12. ábra. A kutatásban résztvevö pedagógusok véleménye a játékról $(N=102$ fö). Forrás: Szerzöko.

Játékkal hatékony an oldható a tanulással, illetve az iskolával kapcsolatos esetleges szorongás.

A játék használatával kiküszöbölhető az egyhangú gyakorlás és a kifáradás.

A játék jól alkalmazható a differenciálás során is.

A gyermeki aktivitás növelése érdekében hatékony a játék alkalmazása.

A játék alkalmat ad arra, hogy létrejöjiön a pedagógus és a gyermek közötti közvetlen A tananyagtartalom elsajátítása biztosítható a játék módszerével.

A játék illeszkedjen az oktatás folyamatához.

A jól megválasztott játék motiváló a gyermek számára a tanórán.

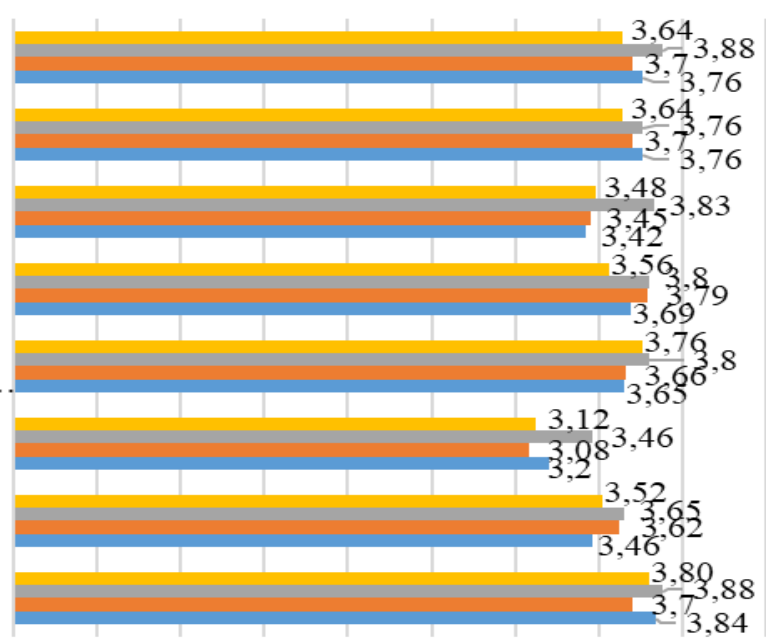

$\square$ Gyógyp. felső $\square$ Gyógyp. alsó $\square$ Többs. felső $\square$ Többs. alsó

\section{Következtetések}

Az első hipotézis, melyben úgy gondoltuk, hogy a gyógypedagógusok az alsó és felső tagozaton egyaránt gyakrabban használják, és több idôt fordítanak a játékra, játékos tevékenységre, mint a többségi oktatásban résztvevő pedagógusok, igazolódott. Eredményeink azt igazolták, hogy a gyógypedagógusok naponta néhány órán, fele részük pedig minden órán alkalmazza a játékot. A gyógypedagógusok megfelelő időt szánnak a képességfejlesztésre és energiát fordítanak a tanulás örömének fenntartására.

A második hipotézisünkben úgy véltük, hogy a gyógypedagógusok gyakrabban használnak saját készítésű eszközöket a tanórai játékokhoz, mint a többségi pedagógusok. A hipotézis igazolódott, a gyógypedagógusok gyakran alkalmaznak saját maguk által készített eszközöket, mert a tanulásban akadályozott tanulók minél hatékonyabb fejlesztése érdekében a tanítási folyamatban speciális eszközökre is szükségük van.

A harmadik hipotézisünk, melyben úgy véltük, hogy a többségi pedagógusok didaktikai játékban használt eszközeik közül az infokommunikációs technológián alapuló eszközök a legnépszerúbbek, igazolódott. A többségi pedagógusok tanórai játékban leggyakrabban használt eszközeik a digitális tábla és más IKT eszközök voltak, tehát ők a többségi gyermekek tanításában mind alsó, mind felső tagozaton a digitális eszközök használatát részesítik előnyben a tanórai játékos tevékenységek során. A technológiai fejlődés következtében a digitalizáció uralta világunkban ez nem meglepő, és valószínú, hogy ez a tendencia fog erősödni, de ugyanakkor a digitális technológia kockázataira is ajánlott odafigyelni.

Konklúzióként megállapítható, a játéknak helye van a pedagógiai munkában, továbbá a tárgyi ismeretekre épített játékok használatát növelni érdemes és a játék minden tantárgyban eredményesen alkalmazható.

Rendkívül hatásos motiváló eszköz, ami által növelhetô tanítványaink teljesítménye, akik szinte észrevétlenül fejlődnek. 


\section{Irodalom}

2011. évi CXC. törvény a nemzeti köznevelésről https:// net.jogtar.hu/jogszabaly?docid=a11001 90.tv

Balogh Éva (2008). Fejlödéslélektan I. Didakt Kft., Debrecen.

Czibere Csilla, Kisvári Anna (2006). Ajánlások tanulásban akadályozott gyermekek, tanulók kompetencia alapú fejlesztésébez. suliNova Kht.

Detre Pál, Szigeti Lajos (1980). Játék. Tankönyvkiadó, Budapest.

Fejes József Balázs (2015). Célok és motiváció. Gondolat Kiadó, Budapest.

Gaál Éva (2000). A tanulásban akadályozott gyermekek az óvodában és az iskolában. In Illyés Sándor (szerk.). Gyógypedagógiai alapismeretek. Eötvös Loránd Tudományegyetem Bárczi Gusztáv Gyógypedagógiai Főiskolai Kar, Budapest.. 429-459.

Gordosné Szabó Anna (2000). Bevez̨etés a gyógypedagógiába. Nemzeti Tankönyvkiadó, Budapest.

Gordosné Szabó Anna (2004). Bevezetô általános gyógypedagógiai ismeretek. Nemzedékek Tudása Tankönyvkiadó Zrt, Budapest.

Józsa Krisztián (2007). Az elsajátítási motiváció. Műszaki Kiadó, Budapest.

Kovács György, Bakosi Éva (2005). Játékpedagógiai ismeretek. Magánkiadás, Debrecen.

Lányiné Engelmayer Ágnes (1992). Gyermeklélektan. Tankönyvkiadó, Budapest.

Maár Tiborné (2009). A játék módszerének alkalmazása a tanítás során. Iskolakultúra, 19(12), 44-55.

Mesterházi Zsuzsa (1995). A tanulási képességről és a tanulási akadályozottságról. Gyógypedagógiai Szemle, 23(1), 12-33.
Mesterházi Zsuzsa (1998). A nehezen tanuló gyermekek iskolai nevelése. Bárczi Gusztáv Gyógypedagógiai Tanárképző Főiskola, Budapest.

Mesterházi Zsuzsa, Szekeres Ágota (2019). A nehežen tanuló gyermekek iskolai nevelése. Eötvös Loránd Tudományegyetem, Bárczi Gusztáv Gyógypedagógiai Kar, Budapest.

Mérei Ferenc, V. Binét Ágnes (2006). Gyermeklélektan. Medicina Könyvkiadó Rt., Budapest.

Miltényi Miklós (1992). Játékos módszerek a történelemtanításban. Iskolakultúra, 2(4), 47-53.

Réthy Endréné (1985). Játék az iskolában. A tanitó, 18(5), 26.

Réthy Endréné (2003). Motiváció, tanulás, tanitás. Nemzeti Tankönyvkiadó, Budapest.

Ryan, R. M., Deci, E. L. (2009). Promoting selfdetermined school engagement: motivation, learning and well-being. In Wentzel, K. R. \& Wigfield, A. (szerk.), Handbook of motivation at school. Routledge. 171-195.

Stöckert Károlyné (1995). Játékpsz̧ichológia. Eötvös József Könyvkiadó, Budapest.

Szabó Ákosné (2008). Metamorfózisok: A debilitástól a tanulási akadályozottságig. Laudáció. In Szabó Ákosné (szerk.), Tanulmányok a tanulásban akadályozottak pedagógiája és határtudományai köréböl. Educatio Társadalmi Szolgáltató Közhasznú Társaság. 11-35.

Tunyogi Erzsébet (2019). Tunyogi gyógyitó játékterápia sérült gyermekek fejlesztésére. Tunyogi Gyógyító Játszóház Alapítvány, Budapest. 